International Journal of Health Sciences
Available online at http://sciencescholar.us/journal/index.php/ijhs
Vol. 3 No. 2, August 2019, pages: $28 \sim 37$
e-ISSN: 2550-696X, p-ISSN: $2550-6978$
https://doi.org/10.29332/ijhs.v3n2.328

\title{
Problems of learning and intervention
}

CrossMark

María Elizabeth Lucas Macías a , María Elena Moya Martinez ${ }^{\text {b }}$

Article history: Received 09 December 2018, Accepted: 30 April 2019, Published: 30 August 2019

\section{Correspondence Author ${ }^{\text {a }}$}

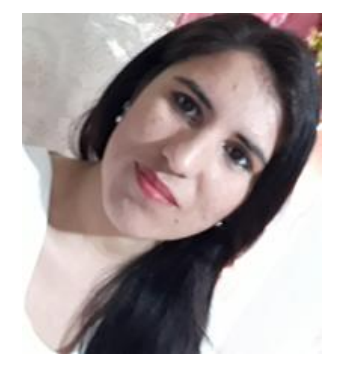

\section{Keywords}

educational needs;

learning;

disorders;

pedagogical;

intervention;

\begin{abstract}
This article refers to the different learning problems that the students present and that should have detected in time by the teachers so that they receive the pedagogical intervention in a timely manner. Among these difficulties are learning disorders, such as dyslexia, dyscalculia, dysgraphia, discography, dyslalia, and attention deficit and hyperactivity. The objective is to meet the educational needs of students with appropriate strategies and methodologies to avoid school failure; the methodology used was a bibliographic review to find out the causes and the treatment that the teacher must apply in the teaching-learning process of the student.
\end{abstract}

e-ISSN: 2550-696X, p-ISSN: 2550-6978 @ Copyright 2019. The Author. SS Journals Published by Universidad Técnica de Manabí. This is an open-access article under the CC BY-SA 4.0 license (https://creativecommons.org/licenses/by-sa/4.0/)

\section{Contents}

Abstract

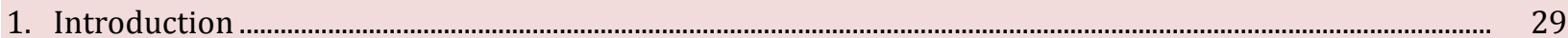

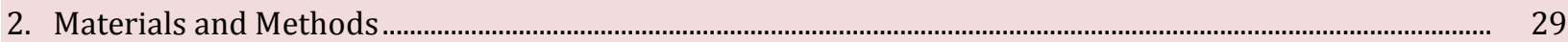

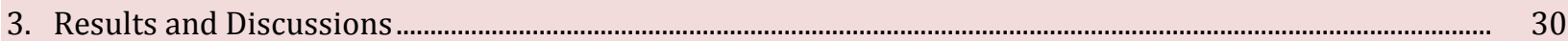

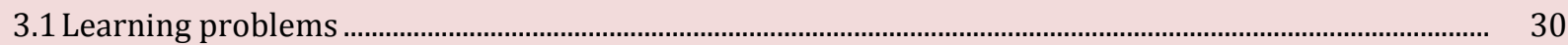

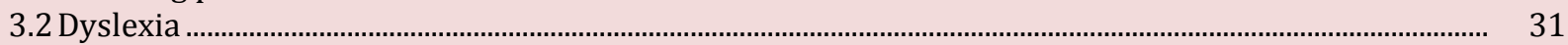

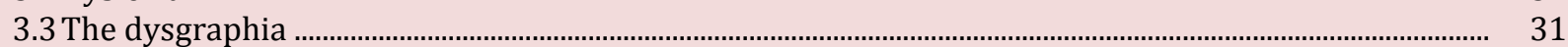

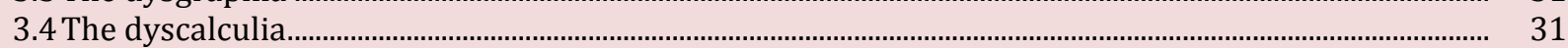

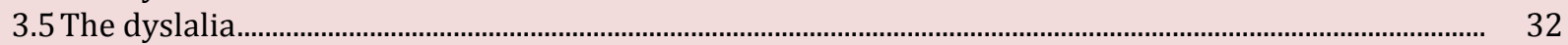

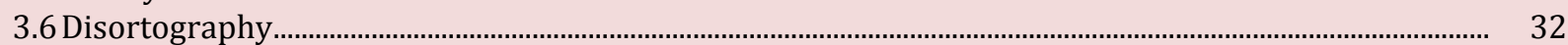

3.7 Attention deficit hyperactivity disorder (ADHD) …........................................................................... 33

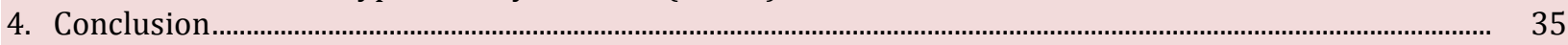

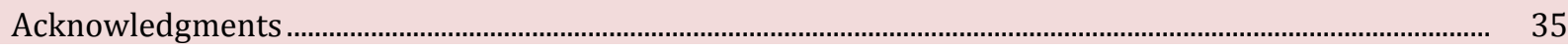

a Pontificia Universidad Católica del Ecuador, Portoviejo, Ecuador

b Pontificia Universidad Católica del Ecuador, Portoviejo, Ecuador 


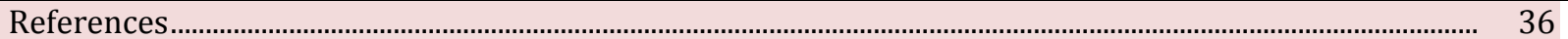

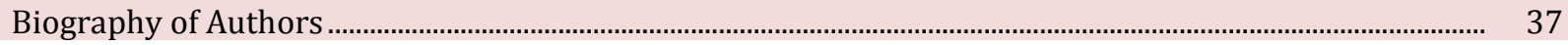

\section{Introduction}

It is surprising to hear a teacher say "Why do I have to worry about a student who does not have a predisposition to learn? Why am I going to spend more time on a student who does not pay attention in class?", Among many other questions, They expose without having greater knowledge of the diversity of students that are inside a classroom.

In a classroom there are students with individual differences, with different rhythms and styles of learning and, above all, something that a teacher must identify in the students is the problems or learning difficulties they present, so that they can intervene pedagogically and find solutions to each case.

Teachers acquire knowledge through experience, identifying the learning problems that their students present, the due process that is carried out so that the specialist issues the respective diagnosis and the pedagogical intervention that they must fulfill as a teacher. It is unacceptable that a teacher does not fulfill its role, that is not able to meet the educational needs of each student, because the result would be the school failure of that student who did not receive the necessary support, for an importance of those who were in charge of their education (Marpaung \& Hambandima, 2018; Menéndez \& Martinez, 2019).

The learning difficulties that students present in the learning process are reflected in their behavior, lack of attention and interest in the activities, they have a slow pace to learn, present problems with language, mathematics, reasoning and relationship with others. Therefore, the teacher must have knowledge of the learning disorders that exist and that these in some cases may be due to an abnormality in the brain's nervous system, causing it to process the information in a different way.

The most common learning problems and disorders found in the classroom are dyslexia, dyslalia, dysgraphia, dyscalculia, historiography, and attention deficit hyperactivity disorder (ADHD).

The objective of this research is for the teacher to know the different learning disorders, the causes, symptoms and how to identify them in the students, so that they carry out the due process and apply the appropriate strategies in the learning process, achieving that the detection and intervention Early learning problems will help improve student learning. However, in order to obtain optimal results, the intervention must occur with the coordinated support of parents, professionals (neurologists, psychologists) and teachers.

The pedagogical intervention in these cases is a challenge for the teacher, who must assume with much responsibility and commitment throughout the process; It is also individualized to obtain effective results in their learning (Estevez et al., 2018; Loor et al., 2019).

\section{Materials and Methods}

The bibliographic and documentary review method has used, where different sources have selected and analyzed in order to base the investigation. In the same way, the bibliographic review contributed with relevant information to the subject of study, which allowed be analyzing and explaining in the development of the scientific work.

In addition, knowledge about the subject was obtained in a precise way to expose the ideas and conclusions related to the subject, the method of analysis-synthesis was also applied when the bibliographical sources were reviewed and the respective reading of documents was done until the basics were known. theoretical, to build new knowledge from previous information that was had, establishing criteria and significantly organizing the abstract definitions of the object of study.

Macías, M. E. L., \& Martinez, M. E. M. (2019). Problems of learning and intervention. International Journal of Health Sciences, 3(2), 28-37. https://doi.org/10.29332/ijhs.v3n2.328 


\section{Results and Discussions}

\subsection{Learning problems}

In order to achieve quality education, the pedagogical practice of teachers must be effective, where an integral formation is privileged, an active teaching, taking into account the diversity in the classroom, the rhythms and learning styles of each student. The task of the teacher is not easy, it is a difficult path to travel, but with clear objectives, sustainable and meaningful learning has achieved in the students, with the use of adequate techniques and methods, investigating different alternatives, to serve as support to those students who need academic reinforcement or pedagogical feedback (Gani et al., 2018).

The attention provided by the teacher to students is personalized, requires academic support to solve the problems detected. From the beginning, the teacher detects the learning difficulties of a student and analyzes not only what their limitations would be to learn, what knowledge they have, what level of instruction they are in, but what kind of help they need, the rhythm and learning styles. After the evaluation and planning of the teaching-learning process, the pertinent curricular adaptations are made so that it receives the adequate attention and is evaluated and valued according to its level of performance (Luque et al., 2006).

Detections of learning difficulties occur when it is perceived that a student does not respond the same as their peers in the evaluation of learning, in educational actions, curricular proposals, in the use of methodologies and strategies in the learning process. Therefore, once detected is essential to act on the resolution of the problems presented, ie, applying new strategies, methodologies, appropriate materials, differentiated assessment, curricular adaptations, motivation, individual tutoring and other ways to meet the educational need what each student has

In educational institutions it is necessary that all professionals, such as social worker, clinical-educational psychologists, and teachers work together, select strategies and design curricular adaptations. The use of individualized activities, respecting the rhythm and style of learning, will favor the learning process of those students who have some learning difficulty.

Next, the different difficulties and learning disorders will be addressed, in order to intervene appropriately with each problem presented to the students in the classroom. Yes it is true, in a classroom, there are also students with SEN associated and not associated with disability and that the teacher must also know how to address these educational needs, this article will be focused on the intervention of cases, such as dyslexia, dysgraphia, dyscalculia, dyslalia, discography, and attention deficit and hyperactivity.

\subsection{Dyslexia}

Is a learning disorder that affects many children of school age and in some cases to adulthood, when they have not received adequate treatment? (Ramirez, 2011), indicates that dyslexia is due to a genetic problem that is reflected in the difficulties it presents in the learning of reading and writing, manifesting itself in a different way according to age.

Children with dyslexia have difficulty reading, distinguishing and memorizing letters, poorly structured sentences, it a learning disorder that needs treatment; but does not disappear as children grow up.

The age to identify dyslexia is at 7 years old and there are strategies that the teacher must apply to improve reading skills, in addition, this difficulty can create problems with other skills, such as reading comprehension, spelling, writing, and mathematics, these symptoms They vary as the child grows.

It is important to discover the strengths of students, constantly motivate them to create reading habits, start with minimal time until they voluntarily encourage themselves to read about a topic of interest, make an adaptation to the needs of the student and use multisensory methods where learning is experimental, experiential and meaningful.

The unconditional support of the family and the school will prevent school failure and advance positively in the learning of literacy. The multisensory method will help the memory, which the student will remember easily, exercising the senses in each phonological activity and the practice must be continuous to obtain better results.

One of the pedagogues who contributed to the battle against dyslexia was María Montessori, creating a method that would facilitate the teaching of reading and writing. Alonso (2017), exposes the Montessori 
method, for the treatment of dyslexia, which consists of the manipulation of objects that symbolize phonemes and is a way for students to be motivated in the learning process.

This method involves selecting properly the pedagogical materials to provoke the interest to learn, to recognize the phonemes by means of objects, where the student must associate the object with the sound, to achieve the attention, be dynamic, attractive and not reach boredom. Therefore, the Montessori method is considered one of the best for the results obtained, because it creates positive responses in the students and a motivating environment.

\subsection{The dysgraphia}

The dysgraphia is the difficulty that the students present with the writing, when the muscles of the hands with the arm are not coordinated, therefore, they cannot dominate the pencil of suitable form that prevents them to write correctly. This learning disorder has diagnosed as dysgraphia and with appropriate treatment can gradually check the problems with writing. Rivas (2011), states that dysgraphia is diagnosed only when there is messy writing, when there are problems to write by hand and express ideas in writing, taking into account the progress that the student has made throughout the learning process writing.

The symptoms presented by the students must have treated in time, so, it may be a neurological problem or it may have related to psychomotor skills. If it has detected from an early age, since the beginning of writing, it will be easier to treat, so it is necessary for the teacher to apply calligraphic, pictographic and cryptographic techniques to overcome dysgraphia.

The strategies and techniques used according to the diagnosis received by the student will help to improve the pace of learning, daily academic activities, communication with the teacher and classmates.

Strength is to develop fine motor skills with activities that require movement in the finger clamps, where the family should be a great support to practice the techniques recommended by the teacher, from how to use the pencil, posture, draw strokes, paint, progression exercises, and inscription and slipped.

\subsection{The dyscalculia}

It is a learning disorder that children present when they have difficulty calculating, where the academic performance of the student and many activities that develop in their daily life, which requires this ability but cannot respond satisfactorily are affected. according to their chronological age and the school level they are in, being in complicated situations in the future, in society, work, personal and professional (García et al., 2016).

The treatment of the dyscalculia is fundamental since it is detected and diagnosed, so that it does not present major obstacles in the daily life, because the mathematics, the calculation, the numbers are part of the day to day of the activities. The work of the teacher with the student in the classroom must have personalized, that can meet the educational need, using the resources and adequate means in teaching to overcome the dyscalculia.

Children who suffer from this disorder have difficulties in signs, numbers and the operations of addition, subtraction, multiplication, and division. To achieve effective treatment, it is necessary to start with an early diagnosis, to offer the children the necessary tools that help in the teaching and learning process.

In the same way, the teacher feeds the learning process with methods that help to advance and not increase the educational delay. Martinez et al., (2017), mention that a way to help children with arithmetic problems is applying an easy method, as is the constant practice of mental and written calculation, with supports and reinforcements, where the student has the opportunities to correct and try again, right and wrong. So the daily practice of mental numerical activities and mental calculation is essential for the treatment of this learning disorder.

Children should be expected to grow and at a higher level to begin treatment. , as they would be less likely to improve, so, they should act immediately to avoid school failure, however, there are students in higher basic education and baccalaureate that have detected this learning disorder, without any treatment, corresponds to carry out the pedagogical intervention, the necessary practices to strengthen the problems presented. 
It is important to know that children cannot have over-pressured with treatment, they should be motivated, work with problem-solving, and have professional help to gradually carry out activities; depending on the progress and level of complexity have the student in their learning

\subsection{The dyslalia}

Is a learning disorder that presents difficulties in speech (Pérez, 2016), states that dyslalia is a disorder in which the child does not articulate or distort some phonemes, caused by inadequate functioning of the articulatory organs, anatomical and/or physiological alterations of peripheral organs of speech, caused by physical injuries or malformations and is not of neurological origin.

Figure 1 shows the peripheral speech organs, which are those that intervene in the production of sound

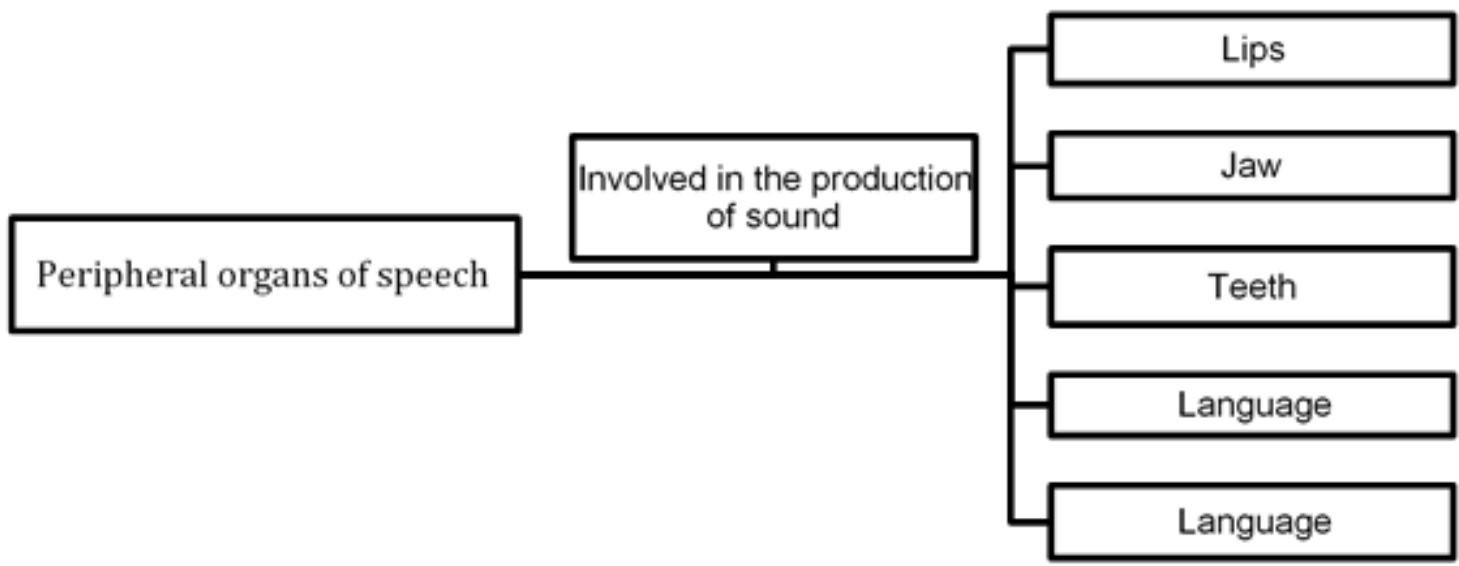

Figure 1. Peripheral organs of speech

This disorder has recognized because certain phonemes have emitted incorrectly, the articulation and pronunciation are not adequate, the intervention must be timely, but a specialist such as a speech therapist is necessary to avoid negative consequences, where the cognitive development of the patient may be affected student and the social relationships of the child.

There are different types of dyslalia and it is pertinent that there is a diagnosis to have treated properly, especially when there are alterations in the peripheral organs of speech, such as injuries or malformations of them. It is necessary the support at home of the parents with the practice of strategies suggested by the speech therapist or specialist who deals with the problem of the dislalia, jointly with all those involved in this process can be investigated on the treatment to be followed in the rehabilitation of the child.

\subsection{Disortography}

Spelling is the correct way to write words, deserves the due attention of educators and learners when they are in the process of learning to write so that they do not present writing problems. Ramírez (2010), refers to discography, which is a learning disorder that involves significant difficulty in the transcription of letters, orthographic rules and the writing of words. These difficulties become noticeable when the student does not write the words correctly, makes mistakes when writing, this being the product of not associating the sound and the spelling or the proper application of the orthographic rules, it can also be due to both cases. 
There are many causes of discography, they can be intellectual, linguistic, pedagogical and perceptive, whatever it may be, there must be control and adequate intervention, some may be temporary and others may be permanent.

The teacher can identify this disorder with dictation techniques, copies and essays; The mistakes made by the student is a guideline that guides the teacher for pedagogical intervention. The intervention must be timely and effective, employing methods and strategies that help to memorize words, rules, practice and constant exercise of correct writing, creating habits in the use of the dictionary and enriching their vocabulary.

\subsection{Attention deficit hyperactivity disorder (ADHD)}

Attention deficit hyperactivity disorder (ADHD) is one of the most frequent in childhood, characterized by lack of attention, they do not control their impulsive behaviors and they may be excessively active. The symptoms they present can considerably affect the school, social and family environment.

In order for a child to receive a diagnosis of ADHD, detailed information about their development at home and school must be available. The assessment of ADHD should be for people who have symptoms and behaviors associated with ADHD and who are seeing their cognitive ability, school, and social environment, among other aspects (Valencia, 2013).

A person who is diagnosed with ADHD has symptoms before the age of 7 and the symptoms they present are relevant and with greater intensity of the normal. A child with ADHD are more vulnerable to poor school performance because they do not control their impulses, behavior, do not remain seated. Symptoms also occur with difficulties paying attention, are easily distracted, and are shy at all times. In addition, it can present both symptoms: hyperactivity-impulsivity and lack of attention.

The causes of ADHD are unknown exactly, despite multiple investigations; however, there is no single cause, it can be due to factors of biological, psychosocial and environmental origin.

Treatment for ADHD can have carried out with behavioral therapies, medications, and adaptations at school; Parents should receive training in behavioral therapy with the therapist, thereby helping at home and at school. The teachers will also apply the therapies in the classroom, for the management of behavior and social relationships. It is important to know that for a person to be diagnosed with ADHD, several tests must be done because it can be a consequence of other problems such as anxiety, depression and learning disorders.

\section{Discussion}

Table 1 shows the names of the authors, theme and year of the published documents, which refer to the problems or learning disorders that students may present. Each author bases his theory and gives his contributions to the subject of study. This research allowed knowing and learning different learning difficulties, their causes, symptoms, and treatment.

Table 1

Authors that substantiate the study topic

\begin{tabular}{|c|c|c|c|}
\hline Author & Theme & Year & Result \\
\hline $\begin{array}{l}\text { Luque, Rodríguez, } \\
\text { Alonso, Caballero, } \\
\text { García, Muñoz, Vega. }\end{array}$ & $\begin{array}{l}\text { Difficulties in Learning: } \\
\text { unification of Diagnostic } \\
\text { Criteria III. Criteria for } \\
\text { Pedagogical Intervention. }\end{array}$ & 2006 & $\begin{array}{l}\text { The teacher detects learning difficulties } \\
\text { and analyzes not only their limitations } \\
\text { to learn, the knowledge they have, but } \\
\text { also what kind of help they need, pace } \\
\text { and style of learning. }\end{array}$ \\
\hline Ramírez & Learning problems at school. & 2011 & $\begin{array}{l}\text { Dyslexia is due to a genetic problem that } \\
\text { is reflected in the difficulties it presents } \\
\text { in the learning of reading and writing, } \\
\text { manifesting itself in a different way }\end{array}$ \\
\hline
\end{tabular}

Macías, M. E. L., \& Martinez, M. E. M. (2019). Problems of learning and intervention. International Journal of Health Sciences, 3(2), 28-37. https://doi.org/10.29332/ijhs.v3n2.328 


$\begin{array}{ll}\text { Alonso } & \text { Proposal of intervention } \\ & \text { from the Montessori method } \\ & \text { for children with writing } \\ \text { difficulties. }\end{array}$

according to age.

2017 Exhibits the Montessori method, for the treatment of dyslexia, which consists in the manipulation of objects that symbolize phonemes and is a way for students to be motivated in the learning process.

\begin{tabular}{|c|c|c|c|}
\hline Rivas & $\begin{array}{l}\text { The reeducation of } \\
\text { dysgraphia: perspectives } \\
\text { neuropsychological and } \\
\text { psycholinguistic. }\end{array}$ & 2011 & $\begin{array}{l}\text { Dysgraphia is diagnosed only when } \\
\text { there is disorganized writing, when } \\
\text { there are problems to write by hand and } \\
\text { express ideas in writing, taking into } \\
\text { account the progress that the student } \\
\text { has made throughout the learning of } \\
\text { writing }\end{array}$ \\
\hline $\begin{array}{l}\text { García, Santana, } \\
\text { Soria, Herrera and } \\
\text { Vila. }\end{array}$ & $\begin{array}{l}\text { Neuropsychology and Neural } \\
\text { Bases of Dyscalculia }\end{array}$ & 2016 & $\begin{array}{l}\text { Dyscalculia is a learning disorder that } \\
\text { children present when they have } \\
\text { difficulty calculating, where the } \\
\text { student's academic performance and } \\
\text { many activities that develop in their } \\
\text { daily lives are affected. }\end{array}$ \\
\hline $\begin{array}{l}\text { Martínez, González, } \\
\text { and Ramírez. }\end{array}$ & $\begin{array}{l}\text { The dyscalculia: a challenge } \\
\text { for the teaching of } \\
\text { mathematics }\end{array}$ & 2017 & $\begin{array}{l}\text { A way to help children with arithmetic } \\
\text { problems is applying an easy method to } \\
\text { perform, as is the constant practice of } \\
\text { mental and written calculation }\end{array}$ \\
\hline Pérez & $\begin{array}{l}\text { A review study on dyslalia } \\
\text { and the educational } \\
\text { intervention }\end{array}$ & 2016 & $\begin{array}{l}\text { Dislalia is a disorder in which the child } \\
\text { does not articulate or distort some } \\
\text { phonemes, caused by anatomical and / } \\
\text { or physiological alterations of the } \\
\text { peripheral organs of speech, caused by } \\
\text { physical injuries or malformations and } \\
\text { is not of origin neurological. }\end{array}$ \\
\hline Ramírez & What is disortography? & 2010 & $\begin{array}{l}\text { It is a learning disorder that involves } \\
\text { significant difficulty in the transcription } \\
\text { of letters, orthographic rules and the } \\
\text { writing of words. }\end{array}$ \\
\hline Valencia & $\begin{array}{l}\text { "Evolution in attention, } \\
\text { cognitive styles and the } \\
\text { control of hyperactivity in } \\
\text { children with a diagnosis of } \\
\text { attention deficit } \\
\text { hyperactivity disorder } \\
\text { (ADHD)" }\end{array}$ & 2013 & $\begin{array}{l}\text { The assessment of ADHD should be for } \\
\text { people who have symptoms and } \\
\text { behaviors associated with ADHD, and } \\
\text { that is being affected by their cognitive } \\
\text { ability, school, and social environment, } \\
\text { among other aspects }\end{array}$ \\
\hline
\end{tabular}

In schools, it is common to find students with different learning disorders, at different educational levels and sublevels, in many cases, they have not have identified and diagnosed, this being one of the main problems of school failure.

It is important that teachers know about the different learning disorders, so they can identify students, so, diversity in the classroom is increasing, each child is different from another, learn differently and require of individualized attention, being a challenge for the teacher.

This research was conducted in order that teachers learn a little of the difficulties and learning disorders, how to intervene to improve the academic performance of students, prepare and commit to providing the necessary support. In the classroom, you can achieve significant changes, with quality education and warmth; 
for this, it is essential that the teacher assumes responsibility and commitment the role he has because a teacher inspires and seeks the happiness of their students.

Therefore, it is a challenge for the teacher to address diversity in the classroom, but the knowledge and timely intervention of the learning problems detected in the classroom will facilitate the educational process. After the detection, the teacher must refer the internal specialist of the institution, so that the father or mother turns to the professional in charge for the diagnosis; there will be positive and favorable responses with the participation of the family and the school.

\section{Conclusion}

The early detection of learning disorders will help reduce symptoms and their inclusion in society, the educational and professional environment, each child has individual differences, interests, abilities and different educational needs, where the teacher considers all these aspects for success in the learning process. The attention that has to be provided is with appropriate strategies, according to the educational need, curricular adaptations, differentiated evaluations and the treatment that corresponds to each difficulty or learning disorder diagnosed. Educating for life is the task of all teachers, learning to recognize the strengths and weaknesses of students, that everyone has the same opportunities, to form integral and unique human beings.

\section{Acknowledgments}

Special recognition is given to Pontificia Universidad Católica del Ecuador Manabí, for her support in the proposal of the master's degree. 


\section{References}

Alonso, S. (2017). Intervention proposal from the Montessori method for children with difficulties in writing. (Degree in Primary Education: Mention Audition and Language). University of Valladolid, Valladolid, Spain. Retrieved from . http://uvadoc.uva.es/handle/10324/26938

Estevez, AG, Roche, JRF, Espinosa, AHR, \& Rodríguez, DL (2018). Social skills training program to prevent alcohol consumption in university students. International Journal of Health Sciences, 2 (3), 4354. https://doi.org/10.29332/ijhs.v2n3.216

Gani, A. A., Ibrahim, N., \& Khaerudin, -. (2018). Multimedia use and learning styles on learning achievement in social studies. International Journal of Social Sciences and Humanities, 2(2), 187-193. https://doi.org/10.29332/ijssh.v2n2.163

García, N., Santana, A., Soria, B., Herrera, B. and Vila, M. (2016). Neuropsychology and Neural Bases of Dyscalculia. Third virtual congress of Morphological Sciences. Recovered from http://www.morfovirtual2016.sld.cu/index.php/Morfovirtual/2016/paper/viewFile/110/147

Ginaya, G., Rejeki, I. N. M., \& Astuti, N. N. S. (2018). The effects of blended learning to students' speaking ability. International Journal of Linguistics, Literature and Culture, 4(3), 1-14.

Loor, Y. C., Zambrano, J. L. Ávila, Loor, M. D. C., Viteri, C. G. V., \& Gámez, M. R. (2019). Professional training incident in local development. International Journal of Social Sciences and Humanities, 3(2), 24-30. https://doi.org/10.29332/ijssh.v3n2.290

Luque, D., Rodríguez, G., Alonso, M., Caballero, J., García, R., Muñoz, T. and Vega, F. (2006). Difficulties in Learning: unification of Diagnostic Criteria III. Criteria for Pedagogical Intervention. Materials for guidance practice, 3 (1), 16. Recovered from http://disde.minedu.gob.pe/handle/123456789/4781

Marpaung, T., \& Hambandima, E. (2018). Collaborative experiential learning. International Journal of Linguistics, Literature and Culture, 4(5), 55-67. https://doi.org/10.21744/ijllc.v4n5.292

Martínez, M., González, O. and Ramírez, M. (2017). The dyscalculia: a challenge for the teaching of mathematics. In memory Compumat, 2017 (17), 2-8. Retrieved from https://www.researchgate.net/profile/Miguel_Cruz6/publication/321807876

Menéndez, E. S., \& Martinez, M. E. M. (2019). Problems of learning and pedagogical intervention. International Journal of Social Sciences and Humanities, 3(2), 105-111. https://doi.org/10.29332/ijssh.v3n2.301

Pérez, E. (2016) A review study on dislalia and educational intervention (End-of-grade work of Primary Education Teacher). University of La Laguna, San Cristóbal, Spain.

Ramírez, C. (2011) Learning problems at school.Horizons Pedagogical, 13 (1), 4. Recovered from https://dialnet.unirioja.es/servlet/articulo?codigo $=4777933$

Ramírez, M. (2010) What is disortography? Themes for education, 10 (9), pág. 1-10. Recovered from https://www.feandalucia.ccoo.es/docu/p5sd7368.pdf

Rivas, M. (2011) The reeducation of dysgraphia:perspectives neuropsychological and psycholinguistic. Psychological Thought, 15 (1), pág. 73-86. Recovered from http://www.scielo.org.co/scielo.php?pid=S165789612017000100006\&script=sci_abstract\&tlng=n

Valencia, J. and Vasco, C. (2009) "Evolution in attention, cognitive styles and control of hyperactivity in children with a diagnosis of attention deficit hyperactivity disorder (ADHD) ". Revista Latinoamericana de psicología, 41 (3), 481-496. Retrieved from http://www.scielo.org.co/pdf/rlps/v41n3/v41n3a07.pdf

Valencia, P. M., Pridgen, E. M., Rhee, M., Langer, R., Farokhzad, O. C., \& Karnik, R. (2013). Microfluidic platform for combinatorial synthesis and optimization of targeted nanoparticles for cancer therapy. ACS nano, 7(12), 10671-10680. 


\section{Biography of Authors}

\begin{tabular}{|l|l||}
\hline & María Elizabeth, \\
Teacher in Basic Education - Aesthetic Culture Specialty in 2005, at the Higher \\
Pedagogical Institute October 23, Montecristi City Bachelor of Basic General \\
Education, Universidad Técnica de Manabí, in the city of Portoviejo. It is currently \\
in the second semester of the Master in Innovation in Education at the Pontificia \\
Universidad Católica del Ecuador, Portoviejo, Manabí, Ecuador \\
Email: sabrinaely20@hotmail.com
\end{tabular}

Macías, M. E. L., \& Martinez, M. E. M. (2019). Problems of learning and intervention. International Journal of Health Sciences, 3(2), 28-37. https://doi.org/10.29332/ijhs.v3n2.328 